\title{
Managing the Inflation Problem in Nigeria using the Fisco-Monetary Approach
}

\author{
By Michael Segun Ogunmuyiwa*
}

This study examined empirically the impact of monetary and fiscal policy management on the problem of inflation in Nigeria. Monthly data spanning from January 2010 to October 2016 on inflation rate, interest rate, exchange rate, narrow money, broad money, government capital expenditure and government recurrent expenditure were obtained from Central Bank of Nigeria $(C B N)$ statistical bulletin and fitted into the regression model. Autoregressive Distributed Lag (ARDL) was employed after ascertaining the stationarity properties of the series through the Augmented Dickey-Fuller (ADF) test. The results showed that broad money supply (M2) and Capital Expenditure (CE) were significant and are positively related (short and long run) to inflation in Nigeria. Exchange rate was significant and positively related to inflation in the long run. The study also revealed that Nigerian inflationary situation is driven by monetary and fiscal policies in the long run. Narrow money has no significant impact on inflation problem both in the short and long run in Nigeria. The study concluded that monetary and fiscal policies have positive impact on inflation in Nigeria and recommended that monetary and fiscal policies should be harnessed, coordinated and sustained with the help of Central Bank of Nigeria in order to combat the problem of inflation in Nigeria. (JELE62, E51, E31)

Keywords: Auto-regression, Fiscal Policy, Inflation, Management, Monetary Policy.

\section{Introduction}

Despite frequently changing the fiscal, monetary and macro-economic policies to manage inflation, several challenges still beset the Nigerian economy. Due to this, Nigeria has not been able to harness her economic potentials for rapid economic development. Inflation has been one of the major problems facing the Nigerian economy because of undue reliance on foreign products thereby making Nigeria an import dependent economy, (Abata et al. 2012). Government has in one way or the other taken the precautionary measures to regulate and manage inflation in order to regulate the economy and to maximize the welfare of the citizens by ensuring that the resources are efficiently allocated among the citizenry. Like any other developing country, Nigeria has adopted three types of public policies to carry out the objectives of income distribution and allocation of resources. These management tools of public policy include: monetary policy, fiscal policy and income policy tools (Nwoko et al. 2016).

\footnotetext{
"Senior Lecturer, Department of Business Administration, Olabisi Onabanjo University, Nigeria.
} 
During inflationary periods opportunity cost of holding money is increased causing inefficient use of real resources in transactions. Therefore, inflation weakens the purchasing power of money and sinks the standard of living of the citizenry (Gbadebo and Mohammed 2015). One of the popular policies used to manage inflation in Nigeria is monetary policy. Therefore, the summation of the economic actions taken by the regulatory authorities' in-charge of regulating or managing the dynamic economic variables that affect changes in the prices of goods and services as well as the value of money is known as monetary policy. In other words, monetary policy is a combination of measures designed to regulate the value, supply and cost of money in an economy in consonance with the level of economic activities (CBN 1992).The ineffectiveness of monetary policy is deepened in an underdeveloped financial market like Nigeria. Despite the application of the monetary policy tools, inflation has continued to pose challenges to the monetary authorities. Some of the reasons include the inability of the monetary authorities to enforce compliance through the monetary channel in the banking and non-banking institutions, and fiscal imbalance characterized with expansionary fiscal policy with deficit budget (Ggor 2011).

Fiscal policy management is another instrument used to curb inflation. Fiscal policy is a measure employed by government to stabilize the economy, specifically by adjusting the levels and allocations of taxes and government expenditures. It is the powerful instrument of stabilization in developing economies in which Nigeria is a typical example. Monetary and fiscal policies play a key role in the promotion of the main government objective of promoting the welfare of its citizens. For a developing economy like Nigeria, it is vital to analyze monetary and fiscal policies transmission effect on inflation because of the need to determine the appropriate channel and the effectiveness of monetary and fiscal policies in managing inflation, among other reasons (CBN 2009).

Prominent among the measures introduced by the Nigerian government are monetary and fiscal policies. Before the deregulation of the economy in 1986, inflation still maintained its single digit level. Sequel to the deregulation of the economy, inflation has been a major macroeconomic problem facing Nigeria. There are several arguments in the literature on the impacts of fiscal and monetary policies in controlling inflation in developed and developing countries. A lot of contrasting opinions on which of the two policies has greater impact or influence in managing inflation exists in the literature. Despite the efficacy of fiscal and monetary policies in other developed economies of the world, the two policies have not sufficiently and adequately yielded any encouraging result in Nigeria.

There is no consensus among economist as to whether government intervention through the use of monetary and fiscal policy will control inflation. This disagreement divided the economy into different schools of thought. Each of them has its view on how variation in monetary and fiscal aggregates could affect inflation and create economic stabilization (Nwoko et al. 2016). In spite of the invaluable significance of economic stabilization policy in the actualization of sustainable development, there seems to be different opinions from several studies on the effect of monetary and fiscal policies on inflation in Nigeria. 
However, previous works on monetary and fiscal policies and inflation problem in Nigeria have been examined by some studies in Nigeria and the direction of their causality has been mixed. Likewise, none of these studies in Nigeria have used monthly data on monetary and fiscal policies variables to ascertain the impact of monetary and fiscal policies on inflation problem in Nigeria. To this end, this study intends to fill this vacuum. The rest of the paper is organized into four sections. Section II is on the literature review while section III focuses on the methodology. Section IV centers on the findings and discussion and section $\mathrm{V}$ is the conclusion and policy recommendations.

\section{Review of Empirical Literature}

The relative impact of fiscal and monetary policies has been studied extensively in many literatures. It has generated large volume of empirical studies with mixed findings. However, the bulk of empirical reviews have not reached a conclusion concerning the relative power of fiscal and monetary policy to affect inflation. Nwoko et al. (2016) examined the extent to which the Central Bank of Nigeria monetary policies could effectively be used to promote economic growth, spanning the period of 1990-2011. The influence of money supply, average price, interest rate and labour force were tested on gross Domestic Product using multiple regression models as the main statistical tool of analysis. The findings from this study indicated that average price and labour force have significant influence on Gross Domestic Product while money supply was not significant. The study recommended that if investment is encouraged, unemployment and lending rate are reduced and economy is stabilized, the central Bank Monetary Policy could be an effective tool.

Abata et al. (2012) assessed how fiscal and monetary policies influenced economic growth and development in Nigeria and showed a mild long-run equilibrium relationship between economic growth and fiscal policy variables in Nigeria. They therefore suggested that for any meaningful progress towards fiscal prudence on the part of government, some powerful pro-stability stakeholders strong enough to challenge government fiscal recklessness will need to emerge. To this end, monetary policy rate and bank lending rates are the most important monetary policy tools that can make or mar the Nigerian real sector. Balami et al. (2016) analyzed the impact of monetary policy on inflation, exchange rate and economic growth. The study used both primary and secondary data. The study reviewed that some Central Bank of Nigeria ( $\mathrm{CBN})$ policies has been under criticism because not all monetary policy tools favour all economic agents. The study recommended that there is need for policy makers to act in order to reduce round tripping which is unhealthy to the economy and the monetary policy must be supported by fiscal policy.

Gbadebo and Mohammed (2015) examined the effectiveness of monetary policy as an anti-inflationary measure in Nigeria. The co-integration and error correction methods approach were employed on quarterly time series data spanning from 1980Q1 to 2012Q4 in order to explore the relationship between 
inflation and monetary impulses. The estimated result for the period covered revealed that interest rate, exchange rate, money supply and oil-price are the major causes of inflation in Nigeria. It was also observed that although in the short run increased in income encouraged inflation, proper utilization of the growth would reduce inflation. The study recommended that Nigerian inflationary situation is driven by monetary impulses. Adigwe et al. (2015) studied the impact of monetary policy on the Nigerian economy. The Ordinary Least Square was used to analyze the data between 1980 and 2010. The result revealed that monetary policy represented by money supply exerts a positive impact on GDP growth but negative impact on the rate of inflation. The study recommended that monetary policy should facilitate favourable investment climate through appropriate interest rates, exchange rate and liquidity management mechanism.

Udude (2014) investigated the impact of monetary policy on the growth of the Nigerian economy between the period of 1981-2012 with the objective of finding out the impact of various monetary policy instruments (money supply, interest rate, exchange rate and liquidity ratio) in enhancing economic growth of the country. The study employed Augmented Dickey Fuller Unit Root, Johansen Cointegration Test and Vector Error Correction Mechanism (VECM). The result of the VECM indicated that only exchange rate exerted significant impact on economic growth in Nigeria while other variables did not. The study concluded that monetary policy did not impact significantly on economic growth of Nigeria. ThankGod and Tamarauntari (2014) investigated the effectiveness of monetary policy on economic growth and inflation in Nigeria over the period of 1970 to 2011. The study revealed that in the short run the level of production is more important in controlling inflation but it is monetary policy variables that matter in the long run.

Kareem et al. (2013) studied the impact of fiscal and monetary instruments on economic growth. OLS regression was employed to analyze the variables employed. The results of the findings revealed that there has been fluctuation in the trend of policy variables in Nigeria. It also showed that broad money and recurrent expenditure have positive relationship with RGDP but recurrent expenditure is 5\% significant with broad money having no significant level. Whereas, narrow money, inflation, interest rate and capital expenditure have negative impact on GDP though interest rate is significant at $10 \%$. The study concluded that narrow money, broad money, government recurrent expenditure and capital expenditure were significant variables that affect economic growth in Nigeria. Other relevant studies on the fisco-monetary management of the inflation problem are Nathan (2012) and Musa et al. (2013). Sequel to the above, monetary policy as a stabilizing variable has been applied more often than fiscal instruments in managing the inflation problem in Nigeria.

\section{Methodology}

The data used were mainly from secondary source collected from Central Bank Statistical Bulletin and the econometric method was used to analyze the data. 
Monthly time series data sourced spanned from January 2010 to October 2016 and were gathered on six independent variables. The variables are: Interest Rate, Narrow Money Supply, Broad Money Supply, Exchange Rate, Government Capital Expenditure and Government Recurrent Expenditure while the dependent variable is the inflation rate.

Model Specification and Estimation Procedure

The model was adapted from Adigwe, Echekoba and Onyeagba (2015) and Gbadebo and Mohammed (2015). The theoretical model estimated is as presented below.

$\mathrm{INF}=f(\mathrm{INT}, \mathrm{M} 1, \mathrm{M} 2, \mathrm{EXR}, \mathrm{RE}, \mathrm{CE})$

Explicitly in behavioural terms equation (1) can be written as:

$\mathrm{INFL}=\lambda_{0}+\lambda_{1} \mathrm{INT}+\lambda_{2} \mathrm{M}_{1}+\lambda_{3} \mathrm{M}_{2}+\lambda_{4} \mathrm{EXR}+\lambda_{5} \mathrm{RE}+\lambda_{6} \mathrm{CE}+\mu_{\mathrm{t}}$

In logarithm form with time subscript, equation (3) will be written as:

$\mathrm{LINFL}=\lambda_{0}+\lambda_{1} \mathrm{LINT}+\lambda_{2} \mathrm{LM}_{1}+\lambda_{3} \mathrm{LM}_{2}+\lambda_{4} \mathrm{LEXR}+\lambda_{5} \mathrm{LRE}+\lambda_{6} \mathrm{LCE}+\mu_{\mathrm{t}}$

Where:

$\mu_{\mathrm{t}}=$ Stochastic Error term

$\lambda_{1}, \lambda_{2}, \lambda_{3}, \lambda_{4}, \lambda_{5}$, and $\lambda_{6}$ are parameters.

$\lambda_{0}=$ constant term.

$\mathrm{L}=$ Natural logarithmic form

$\mathrm{INFL}=$ Inflation rate

INT $=$ Interest rate

$\mathrm{M}_{1} \quad$ = Narrow Money Supply

$\mathrm{M}_{2} \quad=$ Broad Money Supply

EXR = Exchange Rate

$\mathrm{RE}=$ Government recurrent expenditure

$\mathrm{CE} \quad=$ Government capital expenditure

In a-priori terms, it is expected that $\lambda_{1}, \lambda_{2}, \lambda_{3}, \lambda_{4}, \lambda_{5}$ and $\lambda_{6}$ to be $>0$.

\section{Analytical Techniques}

The technique adopted in this research is Autoregressive Distributed Lag (ARDL)/Bounds testing approach for testing the long-run co-integrating relationship among the time series variables. The Bounds testing methodology developed by Pesaran and Shin (1999) has some advantages over the conventional co-integration testing approaches because it can be used with a mixture of $\mathrm{I}(0)$ and I(1) data, and again, it involves just a single-equation set-up, making it simple to implement and interpret. For equation (3), the corresponding ECM is as follow: 
$\Delta$ LINFL $_{\mathrm{t}-\mathrm{i}}=\mathrm{a}_{0}+\sum_{\mathrm{i}=\mathbb{0}}^{\mathrm{n}} \mathrm{a}_{1} \Delta \mathrm{LINF}_{\mathrm{t}-\mathrm{i}}+\sum_{\mathrm{i}=\mathbb{0}}^{\mathrm{n}} \mathrm{a}_{2} \Delta \mathrm{LINT}_{\mathrm{t}-\mathrm{i}}+\sum_{\mathrm{i}=\mathbb{0}}^{\mathrm{h}} \mathrm{a}_{3} \Delta \mathrm{LM}_{\mathrm{t}-\mathrm{i}}+\sum_{\mathrm{i}=0}^{\mathrm{h}} \mathrm{a}_{4} \Delta \mathrm{LM} 2_{\mathrm{t}-\mathrm{i}}$ $+\sum_{\mathrm{i}=\mathbb{0}}^{\mathrm{h}} \mathrm{a}_{5} \Delta \mathrm{LEXR}_{\mathrm{t}-\mathrm{i}}+\sum_{\mathrm{i}=\mathbb{0}}^{\mathrm{m}} \mathrm{a}_{6} \Delta \mathrm{LRE}_{\mathrm{t}-\mathrm{i}}+\sum_{\mathrm{i}=\mathbb{0}}^{\mathrm{h}} \mathrm{a}_{7} \Delta \mathrm{LCE}_{\mathrm{t}-\mathrm{I}}+\mathrm{a}_{8} \Delta \mathrm{LINF}_{\mathrm{t}-\mathrm{i}}+\mathrm{a}_{9} \Delta \mathrm{LINT}_{\mathrm{t}-\mathrm{I}}+$ $\mathrm{a}_{10} \Delta \mathrm{LM}_{\mathrm{t}-\mathrm{i}}+\mathrm{a}_{11} \Delta \mathrm{LM} 2_{\mathrm{t}-\mathrm{i}}+\mathrm{a}_{12} \Delta \mathrm{LEXR}_{\mathrm{t}-\mathrm{i}}+\mathrm{a}_{13} \Delta \mathrm{LRE}_{\mathrm{t}-\mathrm{i}}+\mathrm{a}_{14} \Delta \mathrm{LCE}_{\mathrm{t}-\mathrm{i}}+\mathrm{a}_{15} \mathrm{ECM}_{\mathrm{t}-\mathrm{i}}+\mu_{\mathrm{t}}$

In the above equation, it assumed that a lag length of t-i for the ECM equation. The first part of equation (4) with $\mathrm{a}_{1}, \mathrm{a}_{2}, \mathrm{a}_{3}, \mathrm{a}_{4}, \mathrm{a}_{5}, \mathrm{a}_{6}$ and $\mathrm{a}_{7}$ represents the short run dynamics of the model whereas the second part with $a_{8}, a_{9}, a_{10}$, $a_{11}, a_{12}, a_{13}$ and $a_{14}$ represents the long run equilibrium relationship. The null hypothesis in the equation is $\mathrm{a}_{8}=\mathrm{a}_{9}=\mathrm{a}_{10}=\mathrm{a}_{11}=\mathrm{a}_{12}=\mathrm{a}_{13}=\mathrm{a}_{14}=0$ which means the non-existence of the equilibrium relationship.

In order to determine the time series properties of the variables and to avoid the problem of spurious regression, the data was subjected to Augmented Dickey-Fuller (ADF) Unit Root Test (Dickey and Fuller 1979). As a preliminary step in ARDL/Bound testing, the Augmented Dickey Fully Unit root test was employed to confirm the order of integration of the time series variables. This is necessary because the presence of an order of integration higher than I(1) such as I(2) will invalidate the use of Pesaran and Shin (1999) computed F-statistics which is based on the assumption that the underlying variables must be either $\mathrm{I}(0)$ or $\mathrm{I}(1)$ or mutually integrated.

\section{Results and Discussion}

The descriptive statistics was employed to analyze the trends of monetary, fiscal policies and inflation in Nigeria as analyzed below:

Figure 1. Inflation, Monetary and Fiscal Policy Variables Trend Graphs
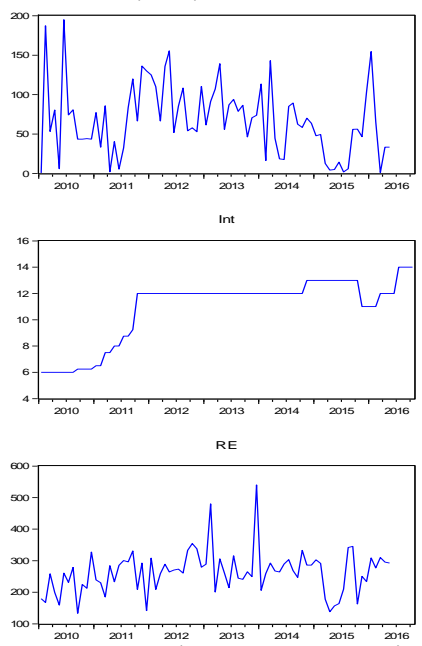

Source: Author's Computation (2017).
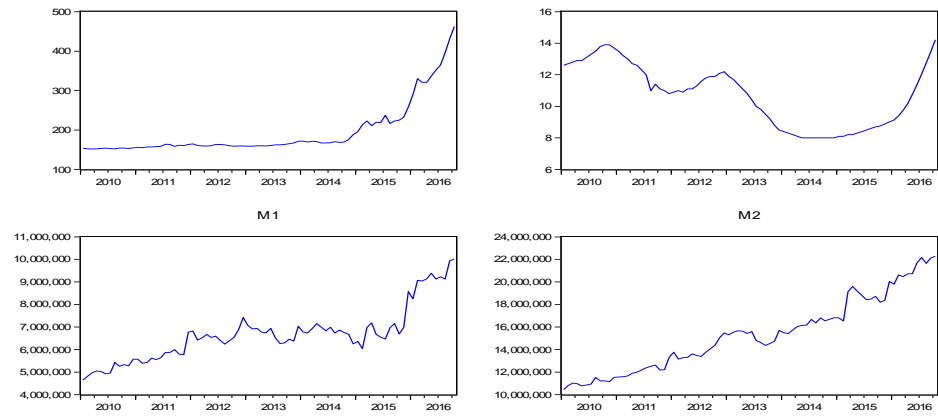

The above charts revealed the trend of inflation rate from January, 2010 to October, 2016. The graph showed that inflation rate was high in 2010 and increased to $14 \%$ and dropped in 2011 to $11 \%$ and later increased a little bit in 
2012. It showed from the graph that the inflation rate was drastically reduced to low level of $8 \%$ in 2014 but gradually increased to $14 \%$ in 2016.

The trend of interest rate in Nigeria during the period under review showed that interest rate was not stable in 2010 and 2011. It was stable from 2012 to 2014 at $12 \%$. It was high and dropped in 2015 . The trend of exchange rate from January 2010 to October, 2016 revealed that the exchange rate was constant from 2010 to 2014 at the rate of one hundred and fifty naira to a dollar. A sharp increase occurred in 2015 and 2016 which implied that the value of naira to a dollar has increased which might be due to a change in policies and the fall in the price of crude oil in the international market. The graph above on Broad money (M1) indicated that amount of money and liquidity in the economy continued to increase from January 2010 to October, 2016 which might contribute to the inflation rate in the country. Narrow money (M2) showed that there has been continuous increase in the supply of currency with non-bank and demand deposit between the periods under review. Recurrent Expenditure revealed that recurrent expenditure was only increased in 2013. It was not stable and it experienced high and low between 2010 and 2016. Finally, capital expenditure showed that during the period under review was not stable. In 2010 it was increased and decreased in 2011. Since then, capital expenditure has been experienced high and low till 2016.

\section{Augmented Dickey Fuller Test (ADF) Unit Root}

The Augmented Dickey Fuller (ADF) unit root was employed to establish the stationarity of the variables. Also, the ARDL Bound Test was employed to test for the presence of long run relationship among the variables. Thereafter, the Autoregressive Distributed Lag (ARDL) was employed to test the short run and long run equilibrium of the variables

Table 1. Unit Root Results (2010:01-2016:10)

\begin{tabular}{|l|c|c|c|c|c|c|c|}
\hline Variables & \multicolumn{7}{|c|}{ Augmented Dickey Fuller Test } \\
\hline & $\begin{array}{c}\text { Level Form } \\
\text { intercept } \\
\text { no trend } \\
\text { intercept } \\
\text { or } \\
\text { constant }\end{array}$ & $\begin{array}{c}\text { With } \\
\text { intercept } \\
\text { and trend }\end{array}$ & $\begin{array}{c}\text { No intercept } \\
\text { no trend }\end{array}$ & $\begin{array}{c}\text { With } \\
\text { intercept or } \\
\text { constant }\end{array}$ & $\begin{array}{c}\text { With } \\
\text { intercept } \\
\text { and trend }\end{array}$ & \\
\hline LCE & -0.8384 & $-7.6840^{* *}$ & $-8.0429 * *$ & $-15.9112^{* *}$ & $-15.7923 * *$ & $-15.6558^{* *}$ & $\mathrm{I}(0)$ \\
\hline LEXR & 0.4542 & $4.9531^{* *}$ & 2.1854 & 2.7364 & $-6.2262^{* *}$ & $-7.4289^{* *}$ & $\mathrm{I}(0)$ \\
\hline LINT & 1.8507 & -1.8271 & -1.4166 & $-8.1712^{* *}$ & $-8.5340^{* *}$ & -8.6516 & $\mathrm{I}(1)$ \\
\hline LM1 & 1.7375 & -0.9111 & -2.3777 & $-9.8379 * *$ & $-10.1714^{* *}$ & $-10.1279 * *$ & $\mathrm{I}(1)$ \\
\hline LM2 & $2.9074 * *$ & -0.3625 & -3.5434 & $-8.5496^{* *}$ & $-9.3346^{* *}$ & $-9.2928^{* *}$ & $\mathrm{I}(0)$ \\
\hline LRE & 0.1960 & $-7.5187 * *$ & $-7.6046^{* *}$ & $-16.2631^{* *}$ & $-16.1693 * *$ & $-16.0698^{* *}$ & $\mathrm{I}(0)$ \\
\hline LINF & $4.9092^{* *}$ & -0.3580 & $-4.2533^{* *}$ & $-3.3430^{* *}$ & $-12.3668^{* *}$ & $-12.2811^{* *}$ & $\mathrm{I}(0)$ \\
\hline
\end{tabular}

Source: Author's Computation (2017).

**Significant at $1 \%$.

Model 1 (with no intercept \& trend) critical value at $1 \%=-2.5961$, $5 \%=1.9452,10 \%=-1.6139$. Model 2 (with constant only) critical value at $1 \%=$ $3.5191,5 \%=-2.900,10 \%=-2.5874$. Model 3: (with intercept and trend) at 1\% = $4.0834,5 \%=-3.4700,10 \%=-3.1620$. 
The result in Table 1 above showed that Capital Expenditure (CE), Recurrent Expenditure (RE), Exchange Rate (EXR), Broad Money Supply (M2) and inflation (INFL) were stationary at level, i.e., I(0) while Interest Rate (INT) and Narrow Money (M1) were stationary at first difference, i.e., I(1). This can be seen by comparing the observed values (in absolute terms) of the ADF test statistics at $1 \%, 5 \%$, and $10 \%$ levels of significance.

Table 2. 4.2 ARDL Bounds Test (for the Presence of Long Run Relationship)

\begin{tabular}{|l|c|c|}
\hline \multicolumn{3}{|l|}{ ARDL Bounds Test } \\
\hline \multicolumn{3}{|l|}{ Included observations: 71} \\
\hline Null Hypothesis: No long-run relationships exist \\
\hline Test Statistic & Value & $\mathrm{K}$ \\
\hline F-statistic & 8.381768 & 6 \\
\hline \multicolumn{3}{|c|}{ Critical Value Bounds } \\
\hline Significance & I0 Bound & I1 Bound \\
\hline $10 \%$ & 2.53 & 3.59 \\
\hline $5 \%$ & 2.87 & 4 \\
\hline $2.5 \%$ & 3.19 & 4.38 \\
\hline $1 \%$ & 3.6 & 4.9 \\
\hline
\end{tabular}

Source: Author's Computation (2017).

The above result in Table 2 showed that there is long run co-integration among variables since F-statistic is more than the upper bound value. This implies that collectively or jointly the independent variables are significant. Therefore, the study would need to proceed to short run relationship of the variables.

\section{The Error Correction Model Results}

The model in Table 3 above examined the impact of monetary and fiscal policies on inflation in Nigeria. It showed the results of the regression having logged all the independent variables involved. The adjusted $\mathrm{R}^{2}$ revealed that $99.6 \%$ of the total variation in the rate of inflation is occasioned by interest rate, broad money, narrow money, exchange rate, government recurrent expenditure and government capital expenditure. Similarly, there is trend among the variables which implies that an increase in the monetary and fiscal policies variables will increase inflation and vice-versa. The F-statistic is significant at $1 \%$ which is showing a general goodness of fit. The Durbin-Watson (DW) statistic has a value of 2.2748 which is more than the upper bound of DW critical value and it shows that there is serial correlation in the model. 
Table 3. ECM Results of Short Run Estimation using ARDL Approach (2010:012016:10)

\begin{tabular}{|l|c|c|c|c|}
\hline Variable & Coefficient & Standard Error & T-Statistic & Probability \\
\hline C & 1.573933 & 0.681918 & 2.308098 & 0.0252 \\
\hline DLOG(INT(-2)) & -0.076273 & 0.033455 & $-2.279896^{* *}$ & 0.0269 \\
\hline DLOG(M1) & 0.016502 & 0.031397 & 0.525595 & 0.6015 \\
\hline DLOG(M2) & 0.089096 & 0.049080 & $1.815322^{*}$ & 0.0755 \\
\hline $\begin{array}{l}\text { DLOG } \\
\text { EXR(-1) }\end{array}$ & -0.080111 & 0.056028 & -1.429836 & 0.1590 \\
\hline DLOG(CE(-2)) & 0.002989 & 0.001459 & $2.048158^{* *}$ & 0.0458 \\
\hline DLOG(RE(-2)) & 0.012318 & 0.005652 & $2.179541^{* *}$ & 0.0340 \\
\hline D(@TREND()) & 0.004619 & 0.000775 & $5.962586^{*} * *$ & 0.0000 \\
\hline ECM(-1) & -0.767320 & 0.101190 & $-7.5829 * * *$ & 0.0000 \\
\hline \multicolumn{4}{|l|}{ Adjusted R ${ }^{2}=0.9963$ D.W.=2.27 F-st=954 } \\
\hline
\end{tabular}

Source: Author's Computation (2017).

*** Significance at 1\%**Significance at 5\%* Significance at $10 \%$.

In the above result, the Error Correction Model was used to determine the short run relationship between variables. The threshold for the ECM is that its coefficient must be less than one, negative and it must be significant. These three properties were met in this result because the coefficient of the ECM was -0.767 which was negative and less than one, using probability value of the ECM, it could be concluded that it is highly significant which implied that the other results obtained from the model could be used to establish the short run relationship between inflation and interest rate, narrow money, broad money, exchange rate, recurrent expenditure and capital expenditure. The coefficient also revealed that there was speed of adjustment between the short run and the long run realities of the monthly co-integrating variables.

From the results, narrow money, broad money, capital and recurrent expenditures have positive relationship with inflation while interest rate and exchange rate have negative relationship with inflation in the short run. The coefficient of broad money (M2) was significant at $10 \%$ and rejected the null hypothesis. The coefficient of interest rate (INT(-2)) is -0.076273 implying that a unit increase in interest rate (INT) lagged for two months would bring about $0.0758 \%$ decrease in inflation (INFL) in the short run. In the same vein, capital and recurrent expenditure were significant and have positive relationship to inflation rate in Nigeria. The null hypothesis is rejected since the variables are significant at 5 percent.

However, exchange rate and narrow money are insignificant in the short run and these imply that the variations with these variables cause no significant changes in inflation in the short run. The exchange rate is negatively related while narrow money is positively related. The explanatory variables have inelastic effect on inflation rate in Nigeria and show that a percentage change in them would bring or lead to a less than proportionate change in inflation in Nigeria. The relationship between inflation and broad money, narrow money, capital and recurrent expenditure are positive which is in line with a priori expectation. Interest and exchange rates are negatively related to inflation and it is against a priori expectation. This is similar to Nenbee and Madume (2011) which showed that 
monetary policy tools have mixed impact on inflation in Nigeria. The study, however, differs from that of Asuquo (2012) and ThankGod and Tamarauntari (2014), which revealed that money supply (M2) and interest rate had significant impact on inflation in Nigeria.

\section{Long Run Estimation using ARDL Approach}

Table 4. Long run Estimation using ARDL Approach (2010:01-2016:10)

\begin{tabular}{|l|c|c|c|c|}
\hline Variable & Coefficient & Standard Error & T-Statistic & Probability \\
\hline C & 2.051209 & 0.776543 & $2.641463^{*}$ & 0.0110 \\
\hline L(INT) & 0.018162 & 0.014805 & 1.226757 & 0.2257 \\
\hline LOG(M1) & 0.021506 & 0.040529 & 0.530638 & 0.5980 \\
\hline L(M2) & 0.116113 & 0.066140 & $1.755563^{*}$ & 0.0853 \\
\hline L(EXR) & 0.068243 & 0.029618 & $2.304120^{* *}$ & 0.0254 \\
\hline L(CE) & 0.012489 & 0.004126 & $3.027076^{* * *}$ & 0.0039 \\
\hline L(RE) & -0.002541 & 0.015213 & -0.166996 & 0.8680 \\
\hline @TREND & 0.006020 & 0.000445 & $13.513605^{* * *}$ & 0.0000 \\
\hline \multicolumn{2}{|l}{ Adjusted R ${ }^{2}=0.9963$ D.W. $=2.27$ F-st $=953.7$} \\
\hline
\end{tabular}

Source: Author's Computation, 2017.

***Significant at 1\%**Significant at 5\%*Significant at $10 \%$.

The result in Table 4 showed the positive value of 2.05 as constant and regression intercept, the independent variables in the study positively affects the dependent variable at constant in the long run and thus conforms to a-priori expectation. Also, capital expenditure is significant at $1 \%$, exchange rate is significant at $5 \%$ and broad money is significant at $10 \%$. Whereas, interest rate, narrow money and recurrent expenditure are not significant and showed that the variations with these variables caused no significant changes in inflation in the long run. The capital expenditure, exchange rate and broad money have highly significant long run equilibrium relationship with inflation problem in Nigeria. A significant level at $1 \%$ level shows a relatively high significance level as compared to the significance at $5 \%$ and $10 \%$ level.

The estimated coefficients show a highly significant positive long term relationship between capital expenditure, exchange rate and broad money supply and inflation rate in Nigeria. A unit change in exchange rate would lead to $0.07 \%$ change in inflation. This shows that exchange rate could have long term effect on inflation in Nigeria. Also, a unit change in broad money supply would lead to $0.12 \%$ increase in inflation. This revealed that money supply in circulation would increase inflation in the long run. The two monetary variables revealed in this study that monetary policy has positive and significant influence on inflation in Nigeria. However, interest rate and narrow money are positively related to inflation though is insignificant in the long run in relation to inflation.

The result conforms to the a-priori expectation which states that interest rate, narrow money, broad money, exchange rate, capital expenditure and interest rate are greater than zero. Only recurrent expenditure is against the a priori expectation which is negatively related in the long run to inflation and is insignificant. 
Summarily, the study shows evidence of long run relationship among the variables. This is in confinement with the findings of Osuala and Jones (2014). Also, the result is in consonance with the study of Gbadebo and Mohammed (2015) in their study titled "Monetary Policy and Inflation Control in Nigeria which concluded that exchange rate and money supply have much long run impact on inflation.

Table 5. Post-Estimation Results (2010:01-2016:10)

\begin{tabular}{|l|c|c|}
\hline Test & Model & Decision \\
\hline ARCH-LM & 0.0357 & Accept $\mathrm{H}_{0}$ \\
(Heteroscedasticity) & $(0.8501)$ & Accept $\mathrm{H}_{0}$ \\
\hline Jarque-Bera & $\begin{array}{c}4.27 \\
(0.147)\end{array}$ & Accept $\mathrm{H}_{0}$ \\
\hline Normality test) & $\begin{array}{c}4.42 \\
(0.1096)\end{array}$ & Accept $\mathrm{H}_{0}$ \\
\hline $\begin{array}{l}\text { (Serial correlation) } \\
\text { Ramsey Reset } \\
\text { (Linearity test) }\end{array}$ & $\begin{array}{c}2.9324 \\
(0.931)\end{array}$ \\
\hline
\end{tabular}

Source: Author's Computation (2017).

Table 5 shows that the estimated models satisfied all the assumptions of the OLS Regression Model and the estimates obtained were reliable, suitable for forecasting and predictions. The results also indicated that there is no evidence of heteroscedasticity since the errors has constant variance, therefore null hypothesis of homoscedasticity was accepted at $5 \%$ level of significance. The error series was also normally distributed, i.e., well behaved as shown by the Jarque-Berra test. The null hypothesis was accepted because the probability value was greater than $5 \%$ level of significance. Breusch-Godfrey LM test was also adopted to determine if the error series was auto-correlated and the null hypothesis of "no autocorrelation was accepted" since the probability value was greater than 5\% level of significance. Similarly, Ramsey Reset was used to test for the linearity of the model and therefore, the $\mathrm{H}_{0}$ was accepted and showed that the model was linear.

\section{Discussion of Findings}

This study investigated the impact of monetary and fiscal policies on inflation in Nigeria. The results showed that capital expenditure, recurrent expenditure, exchange rate and broad money supply were stationary at levels, $\mathrm{I}(0)$ while interest rate and narrow money were stationary at the first difference, I(1). The study has been able to find out that there have been fluctuations in the trend of policy variables in Nigeria (i.e., interest rate, exchange rate, narrow money, broad money, government expenditure and capital expenditure). This implied that an increase in the monetary and fiscal policies variables would increase inflation and vice-versa. The study examined the short run and long run relationship between inflation and fiscal and monetary variables. It was observed that broad money supply (M2) and capital expenditure (CE) were significant and positively related both in the short 
and long run to inflation in Nigeria. Exchange rate was significant and positively related to inflation in the long run but not significant and was negatively related in the short run. Interest rate was significant and negatively related in the short run but not significant in the long-run but positively related to inflation. Narrow money was not significant in the short and long run albeit it has a positive relationship with inflation. Finally, recurrent expenditure was significant and positively related in the short run but not significant and has negative relationship to inflation in the long run.

\section{Conclusions and Policy Recommendations}

In the study, the short run and long run relationships between monetary and fiscal variables with inflation rate were examined in Nigeria. The empirical findings showed that the relationship between inflation and most of the macroeconomic variables were statistically significant. Broad money and capital expenditure were positively related and significant in the short and long run to inflation in Nigeria. The study resolved that there is evidence of long run relationship among variables and revealed that monetary and fiscal policies have long term effect on inflation in Nigeria during the period under review. Therefore, the study concludes that monetary and fiscal policies have significant relationship with inflation problem in Nigeria. This leads to rejecting the null hypothesis of this study which states that there is no significant relationship between monetary and fiscal policies and inflation problem in Nigeria. This study's conclusion is similar to the submission of Gbadebo and Mohammed (2015) which concluded that monetary variables have significant impact on inflation control in Nigeria. The study negates the study of Adigwe et al. (2015) which states that broad money has insignificant influence on inflation in Nigeria. From the findings of this study, it is recommended that:

i. Monetary and fiscal policies should be harnessed, coordinated and sustained with the help of Central Bank of Nigeria in order to enhance the welfare of the citizenry.

ii. The monetary authority should device improved measures of managing the monetary policy in order to achieve price stability. The gap between monetary policy formulation and implementation should be bridged. The non-significance of some of the monetary policy and fiscal policy instruments in the long run is an evidence of a gap between formulation and implementation in Nigeria. Therefore, the implementation mechanism of monetary policy should be checked for effective control of inflation in Nigeria.

iii. Contractionary monetary policy should be implemented to constraint excess money in circulation to achieve low inflationary rate. In addition, monetary policy instruments should be applied properly and timely to put inflation at a permissible level. 
iv. Nigerian government should endeavour to ensure exchange stability in order to control inflation in Nigeria. Over reliance on foreign products should be discouraged by stimulating the productive capacity of the economy particularly in the agricultural sector to increase aggregate supply of food products which has the tendency to reduce inflation rate in the country drastically.

\section{References}

Abata MA, Kehinde JS, Bolarinwa SA (2012) Fiscal, monetary policy and economic growth in Nigeria: A theoretical exploration, International Journal of Academic Research in Economics and Management Sciences 1(5): 75-88.

Adigwe PK, Echekoba FN, Onyeagba JBC (2015) Monetary policy and economic growth in Nigeria: A critical evaluation. IOSR Journal of Business and Management 17(2): 110-119.

Asuquo A (2012) Inflation accounting and control through monetary policy measures in Nigeria: Multi-regression analysis (1973-2010). IOSR Journal of Business and Management 1(2): 53-62.

Balami DA, Ahmed FF, Yusuf AB (2016) Impact of monetary policy in Nigeria on inflation, exchange rate and economic growth. International Journal of Economic and Business Management 2(5): 67-82.

CBN (1992) Monetary Policy Department. Central Bank of Nigeria Statistical Bulletin for several issues. Available at:http//www.cenbank.org/.

Central Bank of Nigeria (CBN) (2009) Annual Economic Report, Central Bank of Nigeria, Abuja. Available at: http//www.cenbank.org/.

Dickey DA, Fuller WA (1979) 'Distribution of the Estimators for Autoregressive Time Series with a Unit Root'. Journal of the American Statistical Association 74: 427431.

Gbadebo AD, Mohammed N (2015) Monetary policy and inflation control in Nigeria. Journal of Economics and Sustainable Development 6(8): 108-116.

Ggor ML (2011) The global monetary shocks and inflation in developing Economy. International Journal of Economic Management 41(26): 186-217.

Kareem RO, Afolabi AJ, Raheem KA, Bashir NO (2013) Analysis of fiscal and monetary policies on economic growth: Evidence from Nigerian democracy. Current research Journal of Economic Theory 5(1): 11-19.

Musa Y, Asare BK, Gulumbe SU (2013) Effect of monetary-fiscal policies interaction on price and output growth in Nigeria. CBN Journal of Applied Statistics 4(1): 55-73.

Nathan PA (2012) The impact of fiscal policy on the Nigerian economy. International Review of Social Sciences and Humanities 4(1): 142-150.

Nenbee SG, Madume PN (2011) Econometric analysis of the impact of fiscal policy variables on Nigeria's economic growth (1970-2009). International Journal of Economic Development, Research and Investment 2(1): 171-183.

Nwoko NM, Ihemeje JC, Anumadu E (2016) The impact of monetary policy on the economic growth of Nigeria. African Research Review: An International Multidisciplinary Journal, Ethiopia 10(3): 192-206.

Osuala AE, Jones E (2014) Empirical analysis of the impact of fiscal policy on economic growth in Nigeria. International Journal of Economic and Finance 16(6): 203-211.

Pesaran MH, Shin Y (1999) "An Autoregressive Distributed Lag Modelling Approach to Cointegration Analysis." In S. Strom (ed) Econometrics and Economic Theory in the 
Vol. 6, No. 3 Ogunmuyiwa: Managing the Inflation Problem in Nigeria ...

20th Century: The Ragnar Frisch Centennial Symposium. Cambridge University Press.

ThankGod OA, Tamarauntari MK (2014) Monetary policy effectiveness, output growth and inflation in Nigeria. International Journal of Economics, Finance and Management 3(6): 301-307.

Udude CC (2014) Monetary policy and economic growth of Nigeria. Journal of Policy and Development Studies 9(1): 234-246. 